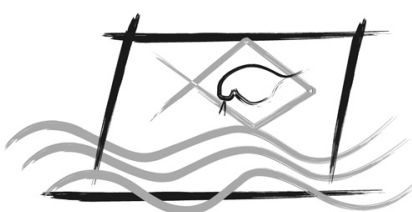

ECOTOX - BRASIL

\title{
Assessment of chromium bioaccumulation in Pseudokirchneriella subcapitata (Korshikov) Hindak by the Central Composite Design (CCD) and Response Surface Methodology (RSM)
}

\author{
P.C. Giloni-Lima ${ }^{1}$; D. Delello²; M.L.M. Cremonez ${ }^{2}$; M.N. Éler ${ }^{2} ;$ V.A. Lima ${ }^{3} \&$ EL.G. Espíndola ${ }^{2}$ \\ ${ }^{1}$ Departament of Biologic Science, State University of West Center, Street Simeão Camargo Varela de Sá, 03, \\ C.E.P. 85040-080, Guarapuava, PR, Brazil. \\ ${ }^{2}$ Water Resources and Applied Ecology Center, São Carlos Engineering School, University of São Paulo, Trabalhador São Carlense \\ Avenue, 400, C. P. 292, C.E.P.13560-970, São Carlos, SP, Brazil \\ ${ }^{3}$ Chemical Department, Federal Technological University of Paraná, C.E.P. 85503-390, Pato Branco, PR, Brazil.
}

(Received April 08, 2010; Accept February 06, 2011)

\begin{abstract}
The effects of chromium bioaccumulation in Pseudokirchneriella subcapitata were evaluated by Central Composite Design (CCD), factorial $2^{2}$ and Response Surface Methodology (RSM). All the models of regression generated by CCD were highly significant, with $R^{2}$ between 77 and $88 \%$, which is the percentual variability in the response that the model can account for. This is indicative of a satisfactory representation of the process models whose data can be used for simulations of response. The maximum shrinkage biovolume presented $28-69 \%$ reduction compared to controls. Results from this study suggest that the smaller algal cells amplify metal binding sites, leading to an increased bioaccumulation and a consequential increased capacity to accumulate chromium. Nevertheless, the absorption capacity decreases for more elevated chromium concentrations and for longer exposure.
\end{abstract}

Keywords: Algae, Biovolume, Central Composite Design, Metal, Selenastrum capricornutum.

\section{Avaliação da bioacumulação de cromo em Pseudokirchneriella subcapitata (Korshikov) Hindak pelo Delineamento Composto Central (DCC) e Metodologia de Superfície de Resposta (MSR)}

\section{Resumo}

Os efeitos da bioacumulação de cromo em Pseudokirchneriella subcapitata foram avaliados pelo Delineamento Composto Central (DCC), fatorial $2^{2}$ e pela Metodologia de Superfície de Resposta (MSR). Todos os modelos de regressão gerados pelo planejamento experimental foram altamente significativos com $R^{2}$ entre 77 e $88 \%$, o qual representa o percentual de variabilidade da resposta que pode ser explicado pelo modelo. Isto é indicativo de uma representatividade satisfatória dos modelos gerados, cujos dados podem utilizados para a simulação de respostas. A faixa de redução do biovolume foi de $28-69 \%$ em comparação com o controle. Os resultados deste estudo sugerem que células menores amplificam sua área de superfície e os sítios de ligação com os metais, conduzindo a um aumento da bioacumulação e um conseqüente aumento da capacidade de retenção do cromo. Apesar disso, a capacidade de bioacumulação decresce nas concentrações mais elevadas de cromo e nos maiores tempos de exposição.

Palavras-chave: Algas, Biovolume, Metais, Planejamento Experimental, Selenastrum capricornutum. 


\section{INTRODUCTION}

Water contamination with heavy metals is currently a very serious problem in the world (Maine et al., 2004; Venay et al., 2007) and represents an important environmental concern due to the toxic effects of metals, and their accumulation throughout food chains leads to serious ecological and health hazards (Malik, 2004). Chromium is a highly toxic non-essential metal for microorganisms and plants (Cervantes et al., 2001).

The interest in chromium $(\mathrm{Cr})$ originates from the widespread use of this metal in various types of industries, such as the metallurgical (steel, iron- and nonferrous alloys), refractory (chrome and chrome-magnesite), and chemical (pigments, electroplating, tanning and other) segments. As a result of industrial processes, large amounts of $\mathrm{Cr}$ compounds are discharged into the environment as liquid, solid, and gaseous wastes which can ultimately cause significant adverse biological and ecological effects (Kotaś \& Stasicka, 2000). In nature, chromium $(\mathrm{Cr})$ exists in two different oxidation states: trivalent (Cr III) and hexavalent (Cr VI) chromium (Kotaś \& Stasicka, 2000; Panda \& Choudhury, 2005), the most stable and most usual forms of the chemical (Cervantes et al., 2001). Both $\mathrm{Cr}$ (III) and Cr (VI) differ in terms of mobility, bioavailability and toxicity. The hexavalent form of the metal, Cr (VI), is considered a more toxic substance than the relatively innocuous and less mobile Cr (III) form (Kotaś \& Stasicka, 2000; Cervantes et al., 2001; Panda \& Choudhury, 2005).

Bioavailability and bioaccumulation of heavy metals in aquatic ecosystems are gaining tremendous significance globally (Vardanyan \& Ingole, 2006). Land plants, water plants and algae have all drawn considerable attention for their capabilities to eliminate heavy metals. Macro and microalgae exhibit constitutive mechanisms for the removal of free metal ions from water, which makes them attractive agents in both water detoxication and remediation processes (PeralesVela et al., 2006). Algae meet all the basic requirements for bioindicators: they are sedentary, their dimensions are suitable, they are easy to identify and to collect, they are widely distributed, and they accumulate metals to a satisfactory level (Conti et al., 2002). The freshwater alga Pseudokirchneriella subcapitata (Korshikov) Hindak, 1990 has become the mainstay in biomonitoring and for evaluating the toxicity of chemicals and wastewater (Ward et al., 2002). The response of $P$. subcapitata to contaminant exposure, such as heavy metals, is typically measured in terms of biomass, cell density, growth rate, etc (Labra et al., 2007).

Recently, the need and importance have been acknowledged of developing validation procedures for models that make it possible to monitor the environmental quality of aquatic ecosystems. The Response Surface Methodology (RSM) and the use of experimental design or the Central Composite Design (CCD) represent the use of techniques that warrant traceability, support validation and produce the subsequent confirmatory validation, in addition to making it possible to understand the effect of several variables on a system by means of a well-defined mathematical model. In particular, statistical design is criterion for choosing experiments efficiently and systematically in order to generate reliable and consistent information (Furlanetto et al., 2003). The experimental design generates a mathematical model in which the parameters are estimated from experimental data. These data are also required for the simulation to occur. This technique is widely used due to its flexibility, simplicity and realism (Kleijnen \& Standridge, 1988).

The objective of this study was evaluated the bioaccumulation of chromium in $P$. subcapitata through to CCD and the use of RSM. The experiments were conducted using algal culture subjected to different chromium concentrations for different exposure times. The metal accumulated by algal cells, and the ratio between chromium content and biovolume were analyzed. An experimental simulation data set was used in order to improve the comprehension of the effect of chromium concentration and exposure time on bioaccumulation and biovolume variation.

\section{MATERIAL AND METHODS}

\section{Algal culture}

The freshwater green algae Pseudokirchneriella subcapitata, formerly known as Selenastrum capricornutum Pintz, (cultures kept at the Ecotoxicology and Ecophysiology Laboratory for Water Organisms of the Water Resources and Applied Ecology Center of the University of São Paulo, São Paulo State, Brazil) was cultivated in L. C. Oligo medium that does not contain ethylenediaminetetraacetic acid (EDTA) (AFNOR, 1980). Culture media were sterilized by autoclaving at $121{ }^{\circ} \mathrm{C}$ during 15 minutes in 2-L glass Erlenmeyer flasks containing $1 \mathrm{~L}$ of the culture medium (ABNT, 2005). The cultures were maintained under continuous cool-white fluorescent lighting $(20 \mu \mathrm{mol}$ photons $\mathrm{m}^{-2} \mathrm{~s}^{-1}$ ) with 12:12 PM light/dark cycle, at $24 \pm 2$ ${ }^{\circ} \mathrm{C}$, with constant aeration and was inoculated with cells to a concentration around $1 \times 10^{4}$ cell $\mathrm{mL}^{-1}$.

\section{Toxicity tests}

Glass Erlenmeyers flasks $(250 \mathrm{~mL})$ with $100 \mathrm{~mL}$ of test medium, were inoculated at an initial cell density corresponding to the beginning of logarithmic phase growth with concentration around the $10^{4}$ cell $\mathrm{mL}^{-1}$. The test solutions were prepared using glass flasks and volumetric pipettes with nominal chromium concentrations $\left(\mathrm{K}_{2} \mathrm{Cr}_{2} \mathrm{O}_{7}\right)$ of 40.0, 41.5, 45.0, 48.5 and $50.0 \mu \mathrm{g} \mathrm{L}^{-1}$, diluted with L. C. Oligo medium. After inoculation, static toxicity tests were maintained for exposures time: 81, 96, 132, 168 and 183h in the same conditions described above for the algal culture maintenance procedure. The chromium concentrations and exposures time were obtained by combinations according to experimental design. The Erlenmeyers were repositioned daily to minimize possible spatial differences in illumination and temperature on growth. 


\section{Algal biovolume}

The algal biovolume was calculated by means of measured linear dimensions that include the full range of microalgal shapes and mathematical equations (Hillebrand et al., 1999). The measurements required in order to calculate the mean biovolume were taken from 30 specimens (or cells) for each run.

\section{Metal analysis}

At the end of the each exposure time, samples with $P$. subcapitata were taken to determine the bioaccumulation, understood as the metal accumulated by algal cells (including the metal absorbed by cells and the metal bound externally). The trial test solutions were filtered through a membrane filter AP20 (Milipore) with $0.45 \mu \mathrm{m}$. The filters were dried and submitted to acid digestion $\left(\mathrm{HNO}_{3}\right.$ and $\left.\mathrm{H}_{2} \mathrm{O}_{2}\right)$ (APHA, 1995). For each digested sample, three unused filters were digested and analyzed as blanks (Van Loon, 1985). Generally, the measured concentration of metal in algal cells is taken as the total amount of metal accumulated by the cells (i.e., externally and internally bound metal) and it is expressed as $\mu \mathrm{g} \mathrm{Cr} \mathrm{mg}{ }^{-1}$ dry weight of algae or $\mu \mathrm{g} \mathrm{Cr}$ cell. ${ }^{-1}$. All the samples were analyzed in triplicates by graphite-furnace atomic absorption spectrometry (Varian AA 220) whose detection limit was $0.0249 \mu \mathrm{g} \mathrm{L}^{-1}$ and quantification limit was $0.0831 \mu \mathrm{g} \mathrm{L}^{-1}$. The data for metal concentration were used to calculate the ratio to the biovolume, expressed as $\mu \mathrm{g} \mathrm{Cr} \mu \mathrm{m}^{-3}$.

\section{Experimental Design and Statistical Analysis}

Central composite design (CCD) was used in order to generate 10 treatment combinations $(k=2)$ for the selected algal toxicity tests is that in which two parameters (exposure time (X1) and chromium concentration (X2) as independent variables. Five levels of each variable were chosen, the upper and lower limits of them, relative to the opted center point (exposure time 132h and chromium concentration $45.0 \mu \mathrm{g} \mathrm{L}^{-1}$ ). The experimental results for the response surface methodology were fitted with a second-order polynomial equation (1) by a multiple regression technique.

$$
Y=b_{0}+b_{1} x_{1}+b_{2} x_{2}+b_{11} x_{1}^{2}+b_{22} x_{2}^{2}+b_{12} x_{1} x_{2}+\varepsilon
$$

$\mathrm{Y}$ is the predicted response; $\mathrm{b}_{0}, \mathrm{~b}_{1}, \mathrm{~b}_{2}, \mathrm{~b}_{11}, \mathrm{~b}_{22}, \mathrm{~b}_{12}$ are constant coefficients. Statistic 7.0 software (Statsoft, USA) was used for regression and graphical analysis of the data. The significance of the regression coefficients was determined by Student's t-test; the second order model equation was determined by Fisher's test. The variance explained by the model is given by the multiple coefficient of determination, $R^{2}$. Based on this parameter estimate, the model can be statistically validated if it is able to reproduce the observed behavior (Faller et al., 2003).

The test factors were coded according to the following regression equation (2):

$$
x_{i}=\left(\frac{X_{i}-X_{0}}{\Delta X_{i}}\right)
$$

where $x_{\mathrm{i}}$ is the coded value and $X_{i}$ is the actual value of its independent variable, $X_{0}$ is the actual value at the center point, and $\Delta X_{i}$ is the step change value. In this case, $X_{1}=$ (time $-132) / 36 ; X_{2}=([\mathrm{Cr}]-45.0) / 3.5$ were used.

\section{RESULTS AND DISCUSSION}

\section{Effect of chromium bioaccumulation in P. subcapitata}

Table 1 shows the actual levels corresponding to the coded settings, the treatment combinations and responses. The bioaccumulation of metal in $P$. subcapitata was evaluated following the analysis of metal accumulated by algal cells at different exposure times and chromium concentrations (Table 1).

The response contour curves (Fig. 1) were plotted for studying the effects of chromium concentration and exposure time in $P$. subcapitata in order for bioaccumulation to be evaluated. Each contour curve represents an infinite number of

Table 1 - Process variables used in the CCD showing the treatment combinations between chromium concentration and exposure time and the mean experimental

\begin{tabular}{|c|c|c|c|c|c|c|c|c|}
\hline \multirow[b]{2}{*}{ Treatment } & \multicolumn{2}{|c|}{$\begin{array}{c}\text { Coded setting } \\
\text { levels } \\
\mathrm{x} 1=\text { time; } \mathrm{x} 2=[\mathrm{Cr}]\end{array}$} & \multicolumn{2}{|c|}{$\begin{array}{c}\text { Actual levels } \\
\mathrm{X} 1=\text { time }(\mathrm{h}) ; \mathrm{X} 2=[\mathrm{Cr}]\left(\mu \mathrm{g} \mathrm{L}^{-1}\right)\end{array}$} & \multirow{2}{*}{$\begin{array}{l}\text { Bio- } \\
\text { accumulation } \\
\left(\mu \mathrm{g} \mathrm{L}^{-1}\right)\end{array}$} & \multirow{2}{*}{$\begin{array}{l}\text { Bio- } \\
\text { volume } \\
\left(\mu \mathrm{m}^{3}\right)\end{array}$} & \multirow{2}{*}{$\begin{array}{l}\text { Percent } \\
\text { biovolume } \\
\text { reduction }\end{array}$} & \multirow{2}{*}{$\begin{array}{l}\text { Ratio }[\mathrm{Cr}] \\
\text { per biov }(\mu \mathrm{g} \\
\left.\mu \mathrm{m}^{-3} \times 10^{-10}\right)\end{array}$} \\
\hline & $\mathrm{x} 1$ & $x 2$ & $\mathrm{X} 1$ & $\mathrm{X} 2$ & & & & \\
\hline 1 & -1 & -1 & 96 & 41.5 & 35.2 & 62.51 & 50.17 & 3.93 \\
\hline 2 & -1 & 1 & 96 & 48.5 & 28.4 & 38.41 & 69.39 & 12.99 \\
\hline 3 & 1 & -1 & 168 & 41.5 & 15.9 & 51.30 & 59.11 & 0.40 \\
\hline 4 & 1 & 1 & 168 & 48.5 & 10.5 & 70.93 & 43.47 & 1.90 \\
\hline 5 & 0 & 0 & 132 & 45.0 & 32.4 & 68.46 & 45.44 & 0.97 \\
\hline 6 & 0 & 0 & 132 & 45.0 & 32.1 & 89.86 & 28.38 & 0.88 \\
\hline 7 & -1.41 & 0 & 81 & 45.0 & 29.0 & 56.49 & 54.97 & 7.22 \\
\hline 8 & 0 & -1.41 & 132 & 40.0 & 24.8 & 52.21 & 58.39 & 2.70 \\
\hline 9 & 1.41 & 0 & 183 & 45.0 & 28.4 & 81.88 & 34.74 & 0.47 \\
\hline 10 & 0 & 1.41 & 132 & 50.0 & 12.2 & 44.87 & 64.24 & 1.01 \\
\hline
\end{tabular}
responses obtained for bioaccumulation, biovolume and the ratio between both, as well as the percentual biovolume reduction in relation to the control. 
combinations of two test variables with the others when their respective zero level is maintained. We noticed that, when the metal is introduced to the culture medium, bioaccumulation is more intense in the first hours of exposure (81h) and for the intermediate chromium concentration $\left(45 \mu \mathrm{g} \mathrm{L}^{-1}\right)$ (Fig. 1). During the experiment, bioaccumulation shows a tendency to decrease.

Bioaccumulation may decrease as a result of a diminution of permeability, active accumulation and absorption surfaces; while active excretion may play an important role (Albergoni et al., 1980). A number of physicochemical factors can influence the uptake of heavy metals by algae, such as light, $\mathrm{pH}$, temperature, and chelating agents (Phillips, 1995). The bioaccumulation level depends on the nature of the chemical compound, algae species, length of exposure, concentration in water (Ivanciuc et al., 2006). The bioaccumulation of chemical compounds in aquatic organisms represents important criteria for ecotoxicological evaluation and hazard assessment (Mackay \& Fraser, 2000; Voutsas et al., 2002).

Table 1 also shows the results obtained for biovolume, its relation to the bioaccumulated metal, and the experimental design that was used to investigate the influence of chromium on bioaccumulation and biovolume in $P$. subcapitata. Biovolume was affected and the reduction ranged between $28 \%$ and $69 \%$ in all treatments, in relations to control cells (data not showed). Biovolume was the highest at $45 \mu \mathrm{g} \mathrm{L} \mathrm{L}^{-1}$, however such values were recorded for higher exposure times at 132 and $183 \mathrm{~h}$ (Fig. 2). The greater percentage of biovolume reduction (Fig. 3) in relation to controls was obtained for more elevated concentration (48.5-50.0 $\mu \mathrm{g} \mathrm{L}^{-1}$ ) and longer exposure time $(168 \mathrm{~h})$. A well documented case of morphological alterations has been reported for the predominant unicellular Scenedesmus acutus in the presence of chromium(VI) (Corradi \& Gorbi, 1993). Peña-Castro et al. (2004) studying morphotypes in chromium stressed cultures of Scenedesmus

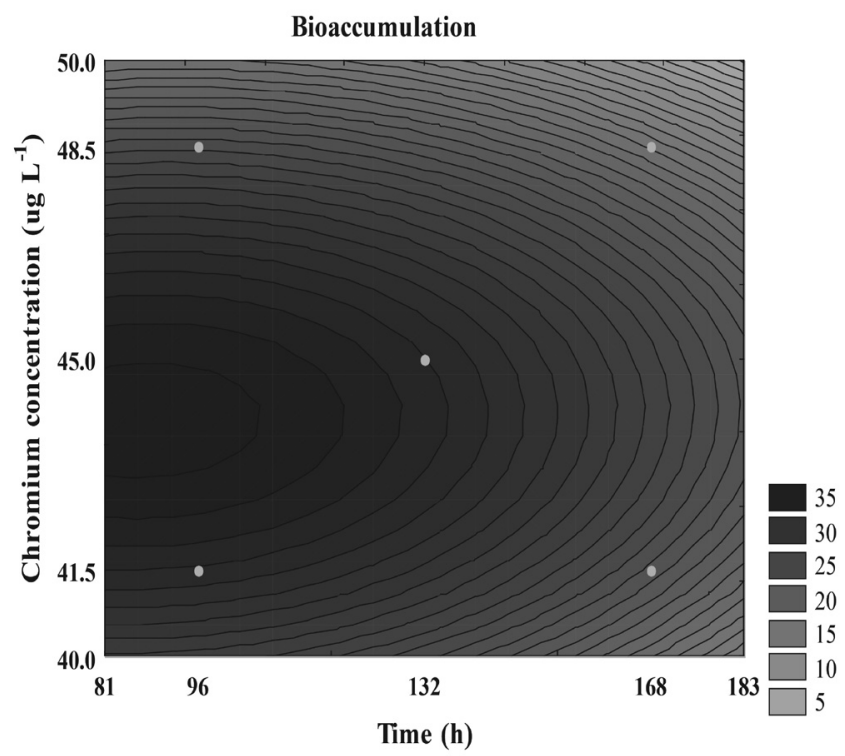

Figure 1. Contour plot of metal bioaccumulation in algae $\left(\mu \mathrm{gCr}_{\mathrm{gDW}} \mathrm{gD}^{-1}\right)$ as a function of chromium concentration (40.0-50.0 $\left.\mu \mathrm{g} \mathrm{L}^{-1}\right)$ and exposure time (81-183 h) for P. subcapitata. incrassatulus, despite of not studied biovolume, were observed cell dimensions changes whose were significantly different from the control for length and width. Other side, Hawkins et al. (2005) tested the effect of Lugol's Iodine on the cell biovolumes of four common freshwater microalgae, and the maximum shrinkage in each species was a $30-40 \%$ reduction compared to the live cell biovolume.

The average algal biovolume in the control measured in this study was $62.73 \mu \mathrm{m}^{3}$ (standard deviation \pm 21.3 ), which was smaller than those examined by Weiner et al. (2004) to $P$. subcapitata at $74.49 \mu \mathrm{m}^{3}$. The highest percentual biovolume reductions in relation to the control were found in chromium concentrations above $48.5 \mu \mathrm{g} \mathrm{L}^{-1}$ and shorter exposure time

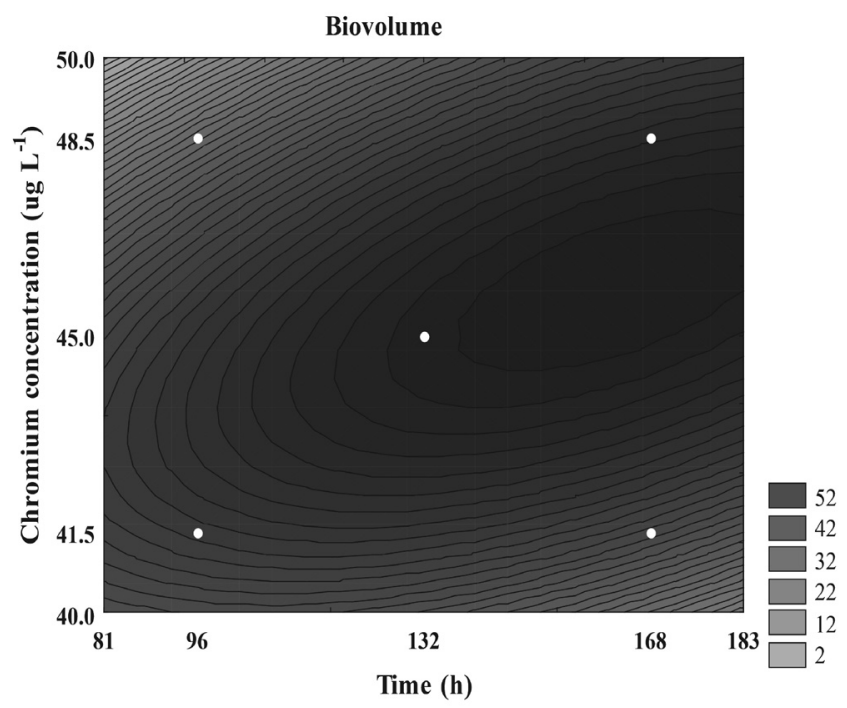

Figure 2 - Contour plot of algal biovolume $\left(\mu \mathrm{m}^{-3}\right)$ as a function of chromium concentration (40.0-50.0 $\left.\mathrm{g} \mathrm{L} \mathrm{L}^{-1}\right)$ and exposure time (81-183 h) for P. subcapitata.

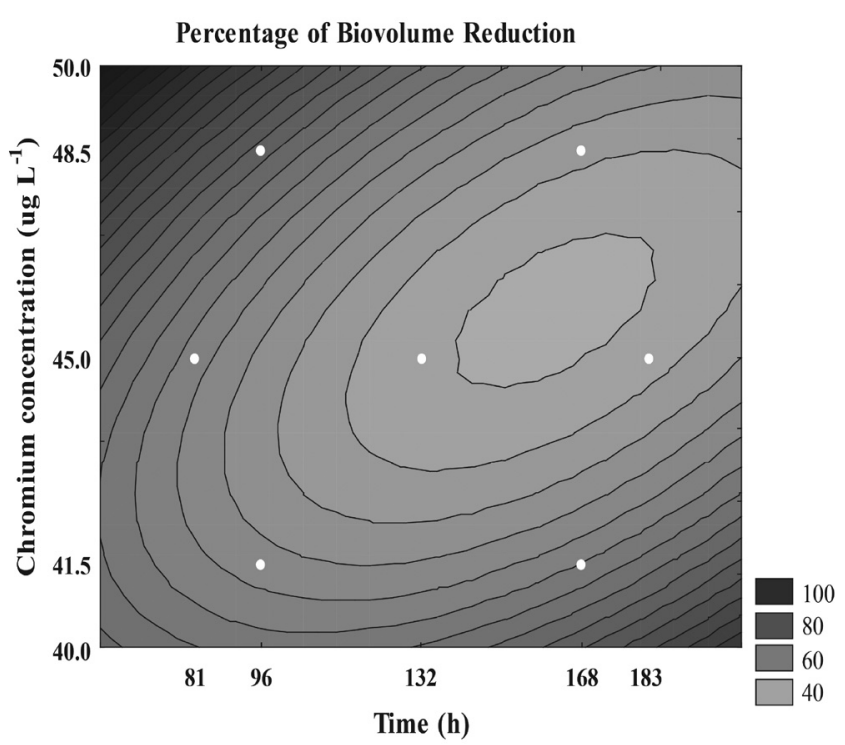

Figure 3 - Contour plot of percentual biovolume reduction (\%) as a function of chromium concentration (40.0-50.0 $\left.\mu \mathrm{g} \mathrm{L}^{-1}\right)$ and exposure time (81-183 h) for $P$. subcapitata. 
(Fig. 3). Although the tested cells of P. subcapitata have experienced considerable reductions in biovolume in this study, Rodgher (2008, dates unpublished) reported increased biovolume for the more elevated concentrations of chromium in comparison to the control. Several authors using optical and/or electron microscopy (Bolaños et al., 1992) and flow cytometry (Franklin et al., 2001) have previously found an increase in cell volume of several species of microalgae in response to toxic levels of metals.

The enhanced bioaccumulation could be related to the observed reduction in biovolume. The highest ratios between the metal accumulated by algal cells and biovolume were found for the shorter exposure times and the elevated chromium concentrations (Fig. 4). The results for biovolume reduction obtained in this study may suggest that smaller cells represent a greater surface area to volume ratios and amplify metal binding sites. In disagree with the results this study, Dabbagh et al. (2007), working with ${ }^{90} \mathrm{Sr}$ bioaccumulation in filamentous cells of Oscillatoria homogenea, suggested that increased biomass and biovolume caused an increment in binding sites and, therefore, in the bioaccumulation capacity. Second these autors, the biomass value had an important role on the bioaccumulation and adsorption of strontium. Since strontium and calcium ions are analog and strontium can be replaced in cyanobacteria metabolic processes. Other side, studies developed by Weiner et al. (2004) verified that both atrazine uptake and the cellular characteristics of microalgae (Isochrysis galbana, Dunaliella tertiolecta, Phaeodactylum tricornutum, Pseudokirchneriella subcapitata, and Synechococcus sp., listed in order of increasing sensitivity) indicated that smaller cells with greater surface area to volume ratios will incorporate more atrazine, and in general, will be more sensitive to atrazine exposure. According to Dönmez et

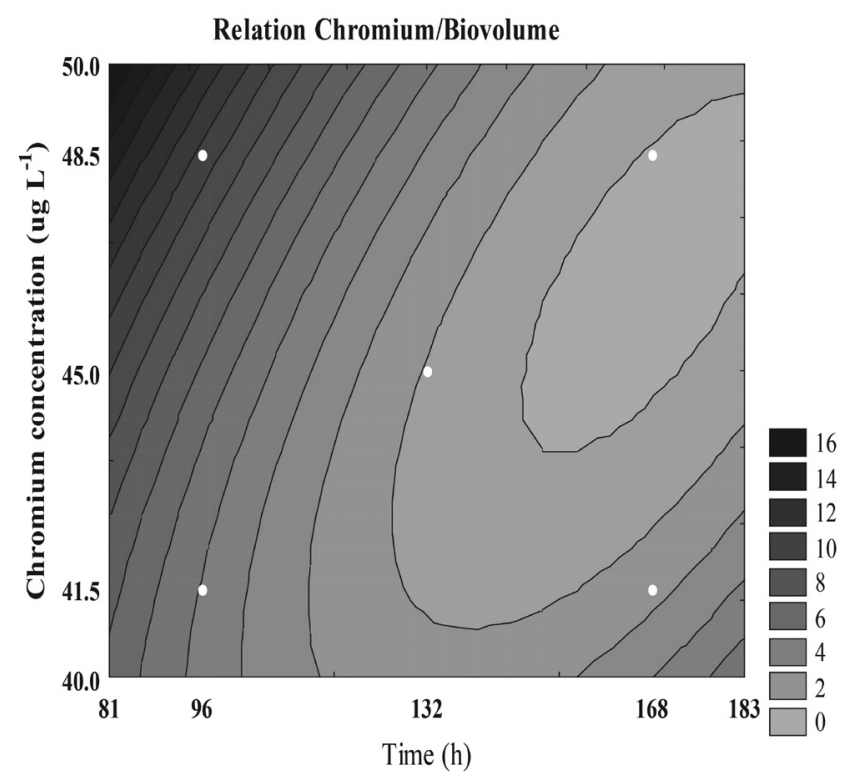

Figure 4 - Contour plot of the ratio between metal accumulated by algal cells and biovolume $\left(\mu \mathrm{g} \mu \mathrm{m}^{-3} \times 10^{-10}\right)$, as a function of chromium concentration (40.0-50.0 $\left.\mathrm{g} \mathrm{L}^{-1}\right)$ and exposure time (81-183 h) for $P$. subcapitata. al. (1999), once the metal ion has diffused to the cell surface, it will bind to sites on the cell surface which exhibit some chemical affinity for the metal, and a number of passive accumulation processes may occur, including adsorption, ion exchange, coordination, complexation, chelation and microprecipitation.

Studies by Rodgher \& Espíndola (2008) found that $P$. subcapitata removed small amounts of chromium from the solution. Travieso et al. (1999) also observed small removal of chromium by the green algae Senedesmus acutus and Chlorella vulgaris, compared to other metals. In addition, Cervantes et al. (2001) suggested that both chromate and dichromate are negatively charged, and there is a limited chance of it being adsorbed by organic materials. A few studies describe $\mathrm{Cr}$ (VI)reducing activities in fungi and plants (but not in algae yet) and the possible relationship of this process with chromate resistance and bioremediation.

On the other hand, Giloni-Lima et al. (2010) observed consistent algal growth inhibition was for the highest chromium concentrations $\left(48-50 \mu \mathrm{g} \mathrm{L}^{-1}\right)$ and the longest exposure time (168-183h). In the early exposure time of metal, the strategy is to reduce the biovolume (reduced surface area/volume), increasing the bioaccumulation. But, if the presence of toxicant occurs at longer exposure times, the species cannot resist the level of stress imposed and reduces growth. Thus, we can say that the species is sensitive and therefore would indicate toxicity to chromium, but would not be suitable for bioremediation. These results are consisted with findings by Labra et al. (2007) and Pereira et al. (2005), who identified consistent growth inhibition and reduction in the number of viable cells, which suggests that potassium dichromate is a strong algal cell pollutant and $P$. subcapitata is a sensitive organism suitable for monitoring the presence of chromium in water.

\section{Model fitting and simulations}

A model fitting was performed for the experimental design. The independent and dependent variables were fitted to the second-order model equation and examined in terms of goodness of fit. The ANOVA (Analysis of Variance) were used to evaluate the adequacy of the fitted model. The $R$-squared value provided a measurement of how much of the variability in the response values could be explained by the experimental factors and their interactions.

On the basis of ANOVA, a second order model (Equation 2) was established, describing the bioaccumulation, the biovolume and the ratio between the metal accumulated by algal cells and the biovolume, and the percentage of biovolume reduction, as a function of chromium concentration and exposure time. The model coefficients estimated by linear regression are shown in Table 2. The ANOVA for the regression model demonstrates that the model is highly significant especially for percentage of biovolume reduction, bioaccumulation and biovolume as it becomes evident from the Fisher's $F$-test (Table 2). The computed $F$-value for the models was higher than the tabular $F$-value (at the 5\% level), indicating that the differences in treatment are highly significant. 
Table 2 - Obtained model and regression coefficients for equation (1), and analysis of variance (ANOVA) for the experiments.

\begin{tabular}{|c|c|c|c|c|}
\hline \multirow[b]{2}{*}{ Term } & \multicolumn{4}{|c|}{ Coefficient estimate ( \pm Standard deviation) } \\
\hline & $\begin{array}{c}\text { Bioaccumulation } \\
\left.\left(\mu \mathrm{gCr}_{\mathrm{gDW}}\right)^{-1}\right)\end{array}$ & Biovolume $\left(\mu \mathrm{m}^{3}\right)$ & $\begin{array}{c}\text { Biovolume } \\
\text { Reduction (\%) }\end{array}$ & $\begin{array}{c}{[\mathrm{Cr}] \text { per Biov }} \\
\left(\mu \mathrm{g} \mu \mathrm{m}^{-3} \times 10^{-10}\right)\end{array}$ \\
\hline$b_{0}$ & $32.055( \pm 3.38)$ & $79.160( \pm 5.90)$ & $36.905( \pm 4.70)$ & $0.925( \pm 1.99)$ \\
\hline$b_{1}$ & $-4.746( \pm 2.07)$ & $7.152( \pm 2.95)$ & $-5.699( \pm 2.35)$ & $-3.020( \pm 0.99)$ \\
\hline$b_{2}$ & $-1.955( \pm 2.46)$ & $-5.755( \pm 3.90)$ & $4.587( \pm 3.11)$ & $1.948( \pm 1.31)$ \\
\hline$b_{11}^{2}$ & $-3.756( \pm 2.07)$ & $-1.857( \pm 2.95)$ & $1.481( \pm 2.35)$ & $1.020( \pm 0.99)$ \\
\hline$b_{22}$ & $-7.050( \pm 2.46)$ & $-16.078( \pm 3.90)$ & $12.815( \pm 3.11)$ & $0.953( \pm 1.31)$ \\
\hline$b_{12}^{22}$ & $0.332( \pm 2.92)$ & $10.933( \pm 4.17)$ & $-8.713( \pm 3.32)$ & $-1.887( \pm 1.41)$ \\
\hline$p$-value & 0.0002 & 0.0001 & 0.0014 & 0.0387 \\
\hline $\mathrm{R}^{2}$ & 77.0 & 88.3 & 88.3 & 78.0 \\
\hline$F$-value & 33.10 & 26.40 & 60.34 & 12.44 \\
\hline$F$ statistic table & 5.12 & 4.74 & 5.32 & 4.74 \\
\hline$F$ ratio $^{\mathrm{a}}$ & 5.88 & 5.57 & 11.34 & 2.62 \\
\hline
\end{tabular}

The elevated values of $R^{2}$, with variations between 0.77 and 0.88 , demonstrate that 77 to $88 \%$ of the variability in the response could be explained by the model and suggests a satisfactory representation of the process model (Heck et al., 2005). In addition, there was a good correlation between the experimental and predicted values (data not shown).

The Student's $t$-test and $p$-values were used to check the significance of each coefficient (data not shown) which, in turn, is necessary to understand the patterns of the mutual interactions between the test variables (Heck et al., 2005). The terms of the second-order model, C (quadratic) for bioaccumulation, biovolume and percentage biovolume reduction were significant $(p<0.05)$ and the interaction of exposure time and chromium concentration $(\mathrm{t} \times \mathrm{C}$ ) for biovolume and percentual biovolume reduction was significant $(p<0.05)$, which indicates that they act as limiting factors and that even small variations in their values will alter the bioaccumulation and the biovolume to a considerable extent. For the ratio between the metal accumulated by algal cells and the biovolume, only the t-linear term was significant with $R^{2}=$ 0.78 , and the $F$ ratio ( $F$-value/ $F$-value tabular) was 2.62 .

The generated models were used to run the simulations of bioaccumulation and biovolume (Figs. 5a and b). The bioaccumulation was smaller in the more elevated time of exposition (168 and $183 \mathrm{~h}$ ) and bigger in the smallest time (81, 96 and $132 \mathrm{~h})$. Figure 5b shows that for the lower concentrations (40.0 and $41.5 \mu \mathrm{g} \mathrm{L}^{-1}$ ), there was an increase in the biovolume until, approximately, $110 \mathrm{~h}$ of exposure to the metal, after which time a decrease was observed. For the center point $\left(45 \mu \mathrm{g} \mathrm{L}^{-1}\right)$ this behavior persisted until after approximately $155 \mathrm{~h}$ of exposure. The smallest biovolume measurements were obtained for the shortest exposure times and for the highest chromium concentrations.

Although, De Schamphelaere et al. (2003) related that more research is needed do mechanistically understanding the relationships observed in the copper toxicity for $P$. subcapitata, the model developed by CCD has a high predictive capacity and will help improve the ecological relevance of current risk assessment. Park et al. (2009) studying combined effects between $\mathrm{pH}$, DOC (Dissolved Organic Carbon) and hardness on acute metal toxicity, developed the empirical models able to predict in D. magna acute toxicity of natural waters and wastewaters containing $\mathrm{Cu}(\mathrm{II})$ or $\mathrm{Cr}(\mathrm{VI})$ as toxicants.

\section{CONCLUSIONS}

Chromium as dichromate is a pollutant that affects algal biovolume in P. subcapitata, and it is possible that this factor causes increased bioaccumulation of metal even in shorter exposure time. Our results suggest that smaller algal cells amplify the metal binding sites, increasing bioaccumulation and consequently their capacity to retain chromium. This hypothesis

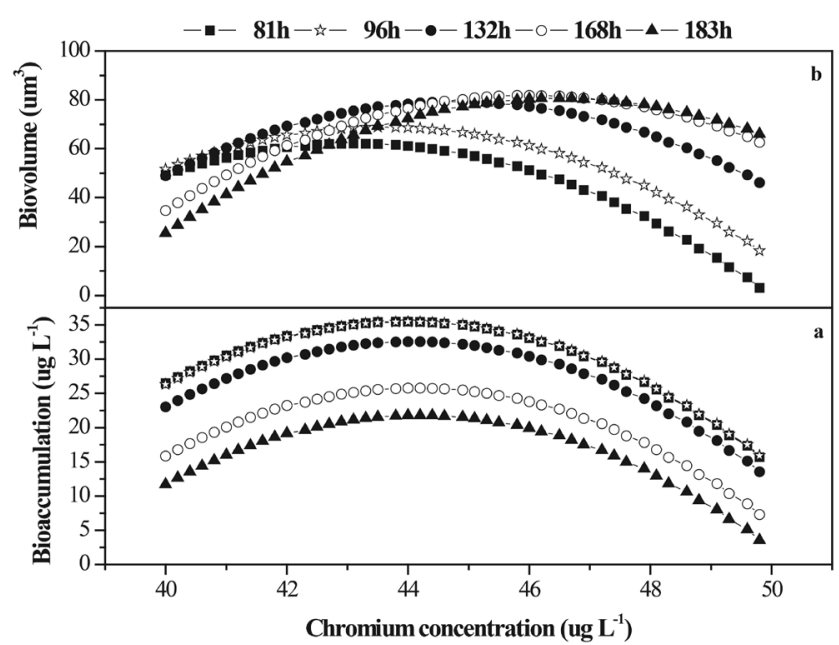

Figure 5 - Simulations of (5a) bioaccumulation $\left(\mu \mathrm{gCr}_{\mathrm{gDW}} \mathrm{gD}^{-1}\right)$ and $(5 \mathrm{~b})$ biovolume $\left(\mu \mathrm{m}^{3}\right)$ based on the model parameters which were estimated from the experimental data. 
could justify the recommendation of $P$. subcapitata as a suitable organism for bioremediation. The CCD and the RSM are useful tools in order to asses how exposure time and chromium (VI) concentration affect bioaccumulation in P. subcapitata.

\section{ACKNOWLEDGEMENTS}

We are grateful for the financial support from the São Carlos Engineering School, the Water Resources and Applied Ecology Center, and the University of São Paulo, and for the assistance from the University State of West Center (UNICENTRO). We wish to thank Dr. Liane Biehl Printes for the valuable comments and suggestions on the manuscript.

\section{REFERENCES}

ALBERGONI, V., PICCINNI, E. \& COPPELlOTTI, O., 1980, Response to heavy metals in organisms. I. Excretion and accumulation of physiological and non physiological metals in Euglena gracilis. Comp. Biochem. Physiol., 67: 121-127.

APHA (AMERICAN PUBLIC HEALTH ASSOCIATION) 1995, Standard Methods for the Examination of Water and Wastewater, 19th ed. Washington-DC.

ABNT, (ASSOCIAÇÃO BRASILEIRA DE NORMAS TÉCNICAS) 2005, Ecotoxicologia aquática, toxicidade crônica - Método de ensaio com algas (Chlorophyceae). NBR12468.

AFNOR,(ASSOCIATIONFRANÇAISENORMALISATION)1980, Essais deseaux Determination de I'inhibition de Scenedesmus subspicatus par une substance. Norme experimentale T90-304.

BOLAÑOS, L., CARCÍA-GÓNZALEZ, M., MATEO, P. \& BONILLA, I., 1992, Differential toxicological response to cadmium in Anabaena strain PCC 7119 grown with $\mathrm{NO}_{3}$ or $\mathrm{NH}_{4}$ as nitrogen source. J. Plant Physiol., 140: 345-349. doi: 10.1016/ S0176-1617(11)81090-4.

CERVANTES, C., CAMPOS-GARCÍA， J., DEVARS, S., GUTIÉRREZ-CORONA, F., LOZA-TAVERA, H., TORRESGUZMÁN, J. C.\& MORENO-SÁNCHEZ, R., 2001, Interactions of chromium with microorganisms and plants. FEMS Microbiol. Rev., 25: 335-347. doi: 10.1111/j.1574-6976.2001.tb00581.x.

CONTI, M. E., TUDINO, M. B., MUSE, J. O.\& CECCHETTI, G., 2002, Biomonitoring of heavy metals and their species in the marine environment: the contribution of atomic absorption spectroscopy and inductively coupled plasma spectroscopy. Res. Trends Appl. Spectrosc., 4: 295-323.

CORRADI, M.G. \& GORBI, G., 1993, Chromium toxicity on two linked trophic levels. II Morphophysiological effects on Scenedesmus acutus. Ecotoxicol. Environ. Saf., 25: 72-78. doi:10.1006/eesa.1993.1008.

DABBAGH, R., GHAFOURIAN, H., BAGHVAND, A., NABI, G. R., RIAHI, H. \& FAGHIH, M. A. A., 2007, Bioaccumulation and biosorption of stable strontium and ${ }^{90} \mathrm{Sr}$ by Oscillatoria homogenea cyanobacterium. J. Radioanal. Nucl. Chem., 272: 53-59. doi: 10.1007/s10967-006-6785-4.

DE SCHAMPHELAERE, K. A. C., VASCONCELOS, F. M., HEIJERICK, D. G., TACK, F. M. G., DELBEKE, K., ALLEN, H. E. \& JANSSEN, C. R., 2003, Development and field validation of a predictive copper toxicity model for the green alga Pseudokirchneriella subcapitata. Environ. Toxicol. Chem., 22: 2454-2465. doi: 10.1897/02-499.

DÖNMEZ, G. Ç., AKSU, Z., OZTÜRK, A. \& KUTSAL, T., 1999, A comparative study on heavy metal biosorption characteristics of some algae. Process Biochem., 34: 885-892. doi: 10.1016/ S0032-9592(99)00005-9.
FALLER, D., KLINGMÜLLER, U.\& TIMMER, J., 2003, Simulation Methods for Optimal Experimental Design in Systems Biology. Simulation, 79: 717-725. doi: 10.1177/0037549703040937.

FRANKLIN, N. M., STAUBER, J. L. \& LIM, R. P., 2001, Development of flow cytometry-based alga bioassays for assessing toxicity of copper in natural waters. Environ. Toxicol. Chem., 20: 160-170. doi: 10.1002/etc.5620200118.

FURLANETTO, S., ORLANDINI, S., MURA, P., SERGENT, M. \& PINZAUTI, S., 2003, How experimental design can improve the validation process. Studies in pharmaceutical analysis. Anal. Bioanal. Chem., 377: 937-944. doi: 10.1007/s00216-003-2189-2.

GILONI-LIMA, P. C.; DELELLO, D.; CREMONEZ, M. L. M.; ÉLER, M. N.; LIMA, V. A. \& ESPÍNDOLA, E. L. G., 2010, A study of the effects of chromium exposure on the growth of Pseudokirchneriella subcapitata (Korshikov) Hindak evaluated by Central Composite Design (CCD) and Response Surface Methodology (RSM). Ecotoxicol., 19: 1095-1101. doi: 10.1007/ s10646-010-0491-2.

HAWKINS P. R., HOLLIDAY, J., KATHURIA, A. \& BOWLING, L., 2005, Change in cyanobacterial biovolume due to preservation by Lugol's Iodine. Harmful Algae, 4: 1033-1043. doi: 10.1016/j. hal.2005.03.001.

HECK, J. X., SOARES, L. H. B. \& AYUB, M. A. Z., 2005, Optimization of xylanase and mannanase production by Bacillus circulans strain BL53 on solid-state cultivation. Enz. Microbial Technol., 37: 417-423. doi:10.1016/j.enzmictec.2005.02.015.

HILLEBRAND, H., DÜRSELEN, C., KIRSCHTEL, D., POLLINGHER, U. \& ZOHARY, T., 1999, Biovolume calculation for pelagic and benthic microalgae. J. Phycol., 35: 403-424. doi: 10.1046/j.1529-8817.1999.3520403.x.

IVANCIUC, T., IVANCIUC, O., KLEIN, D. J., 2006, Modeling the bioconcentration factors and bioaccumulation factors of polychlorinated biphenyls with posetic quantitative superstructure/activity relationships (QSSAR). Mol. Divers., 10: 133145. doi: 10.1007/s11030-005-9003-3.

KLEIJNEN, P. C. \& STANDRIDGE, C. R., 1988, Experimental design and regression analysis in simulation: An FMS case study. Eur. J. Oper. Res., 33: 257-261. doi: 10.1016/03772217(88)90168-3.

KOTAŚ, J. \& STASICKA, Z., 2000, Chromium occurrence in the environment and methods of its speciation. Environ. Pollut., 107: 263-283. doi: 10.1016/S0269-7491(99)00168-2.

LABRA, M., BERNASCONI, M., GRASSI, F., MATTIA, F. D., SGORBATI, S., AIROLDI, R. \& CITTERIO, S., 2007, Toxic and genotoxic effects of potassium dichromate in Pseudokirchneriella subcapitata detected by microscopy and AFLP marker analysis. Aquatic Bot., 86: 229-235. doi: 10.1016/j.aquatic.2006.10.006.

MACKAY, D. \& FRASER, A., 2000, Bioaccumulation of persistent organic chemicals: mechanisms and models. Environ. Pollut., 110: 375-391. doi:10.1016/S0269-7491(00)00162-7. doi:10.1016/S0269-7491(00)00162-7

MAINE, M. A., SUÑE, N. L.\& LAGGER, S. C., 2004, Chromium bioaccumulation: comparison of the capacity of two floating aquatic macrophytes. Water Res., 38: 1494-1501. doi: 10.1016/j. watres.2003.12.025

MALIK, A., 2004, Metal bioremediation through growing cells. Environ. Intern., 30: 261-278. doi:10.1016/j.envint.2003.08.001.

PANDA, S. K. \& CHOUDHURY, S., 2005, Chromium stress in plants. Braz. Soc. Plant Physiol., 17: 95-102. doi: 10.1590/ S1677-04202005000100008.

PARK, E. J., JO, H. J. \& JUNG, J., 2009, Combined effects of pH, hardness and dissolved organic carbon on acute metal toxicity to Daphnia magna. J. Ind. Eng. Chem., 15: 82-85. doi: 10.1016/j. jiec.2008.08.007.

PEÑA-CASTRO, J. M., MARTÍNEZ-JERÓNIMO, F., ESPARZAGARCÍA, F., CAÑIZARES-VILLANUEVA, R. O., 2004, Phenotypic plasticity in Scenedesmus incrassatulus 
(Chlorophyceae) in response to heavy metals stress. Chemosphere, 57: 1629-1636. doi:10.1016/j.chemosphere.2004.06.041.

PERALES-VELA, H. V., PEÑA-CASTRO, J. M.\& CAÑIZARESVILLANUEVA, R. O., 2006, Heavy metal detoxification in eukaryotic microalgae. Chemosphere, 64: 1-10. doi:10.1016/j. chemosphere.2005.11.024.

PEREIRA, M. J., RESENDE, P., AZEITEIRO, U. M., OLIVEIRA, J. \& FIGUEIREDO, D. R., 2005, Differences in the effects of metals on growth of two freshwater green algae Pseudokirchneriella subcapitata (Korshikov) Hindak and Gonium pectorale Müller. Bull Envrion. Contam. Toxicol., 75: 515-522. doi: 10.1007/ s00128-005-0782-0.

PHILLIPS, D. I. H., 1995, Bioaccumulation. In: P. Calow (Ed.), Handbook of Ecotoxicology. Blackwell Science. pp. 378-396.

RODGHER, S. \& ESPÍNDOLA, E. L. G., 2008, Influence of algal densities on toxicity of chromium to Ceriodaphnia dubia (Cladocera, Crustacea). Braz. J. Biol., 68: 341-348. doi: 10.1590/ S1519-69842008000200015.

TRAVIESO, L., CAÑIZARES, R. O., BORJA, R., BENÍTEZ, F., DOMINGUEZ, A. R., DUPEYRÓN, R. \& VALIENTE, V., 1999, Heavy metal removal by microalgae. Bull. Environ. Contam. Toxicol., 62: 144-151. doi: 10.1007/s001289900853.

VAN LOON, J. C., 1985, Selected methods of trace metal analysis.
USA: Wiley.. 357p.

VARDANYAN, L. G. \& INGOLE, B. S., 2006, Studies on heavy metal accumulation in aquatic macrophytes from Sevan (Armenia) and Carambolim (India) lake systems. Environ. Intern., 32: 208218. doi: 10.1016/j.envint.2005.08.013.

VENAY, P., MOUSSARD-GAUTHIER, C. \& HITMI, A., 2007, Interaction of bioaccumulation of heavy metal chromium with water relation, mineral nutrition and photosynthesis in developed leaves of Lolium perenne L. Chemosphere, 68: 1563-1575. doi:10.1016/j.chemosphere.2007.02.052.

VOUTSAS, E., MAGOULAS, K. \& TASSIOS, D., 2002, Prediction of the bioaccumulation of persistent organic pollutants in aquatic food webs. Chemosphere, 48: 645-651. doi:10.1016/S00456535(02)00144-3.

WARD, T. J., RAUSINA, G. A., STONEBRAKER, P. M. \& ROBINSON, W. E., 2002, Apparent toxicity resulting from the sequestering of nutrient trace metals during standard Selenastrum capricornutum toxicity tests. Aquatic Toxicol., 60: 1-16. doi:10.1016/S0166-445X(01)00259-4.

WEINER, J. A., DELORENZO, M. E. \& FULTON, M. H., 2004, Relationship between uptake capacity and differential toxicity of the herbicide atrazine in selected microalgal species. Aquatic Toxicol., 68: 121-128. doi:10.1016/j.aquatox.2004.03.004. 